\title{
Kocadere Havzasında Sediment Veriminin Arazi Ölçümlerine ve MUSLE Modeline Dayalı Olarak Tahmin Edilmesi
}

\author{
Gülay YILMAZ1, * ～Lutfullah ARUĞASLAN' Gözen YÜCEERIM'
}

'Uluslararası Tarımsal Araștırma ve Eğitim Merkezi, İzmir-Türkiye

\begin{abstract}
*Sorumlu yazar e-mail (Corresponding author e-mail): gulay.yilmaz@tarimorman.gov.tr
Geliș tarihi (Received) : 09.03.2020

Kabul tarihi (Accepted): 02.10.2020

DOI: $10.21657 /$ topraksu.700706
\end{abstract}

\section{Öz}

Türkiyenin içinde bulunduğu coğrafi konum, topoğrafya, toprak özellikleri, erozyona elverișli jeomorfolojik yapı, arazi kullanımındaki değișimler ve iklim koșulları toprakların erozyona karșı duyarlıı̆ı̆ı artırmaktadır. Bu nedenle erozyon ve onun sonucu olan sedimantasyon, toprak ve su kaynaklarıyla ilgili en önemli problemlerdendir. Balıkesir-Bigadiç Kocadere Havzasında 2009-2013 yılları arasında yürütülen bu araștırmada, alt havzada yağıș, akım ve süspanse sediment ölçümlerine dayalı olarak, havza sediment veriminin belirlenmesi amaçlanmıștır. Araștırmada, 2009-2013 yıllarını kapsayan 5 yıllık ölçüm sonuçları değerlendirilmiștir. Söz konusu periyotta otomatik sediment örnekleyici ile gerçekleștirilen süspanse sediment örneklemelerine ve akım verilerine dayalı olarak havzanın sediment anahtar eğrisi çıkarılmıștır. Buna göre alt havza sediment verimi 2.11 ton ha-1 $\mathrm{yıl}^{-1}$ olarak belirlenmiștir. Aynı zamanda, havza sediment verimini tahmin etmek amacıyla MUSLE (Modified Universal Soil Loss Equation) eșitliği kullanılmıștır. Araștırma periyodu için MUSLE ile tahmin edilen sediment verimi ise 2.22 ton ha-1 $\mathrm{yl}^{-1}$ olmuștur. MUSLE modelinin havza koșullarında uygulanabilirliği, 13 adet bireysel olay süresince arazide ölçülen sediment verisiyle test edilmiș ve elde edilen belirtme katsayısı değeri 0.92 olmuștur. Yüksek akımlar için sediment verimi tahmininde MUSLE daha iyi sonuçlar vermiștir.

Anahtar Kelimeler: Balıkesir Bigadiç, havza, MUSLE, sediment verimi, toprak erozyonu

\section{Estimation of Sediment Yield Based on Field Measurements and MUSLE Model in Kocadere Watershed}

\begin{abstract}
The geographical location, topography, soil characteristics, favorable geomorphological structure to erosion, land use changes and climatic conditions of Turkey, increase soil sensitivity to erosion. Therefore, soil erosion and consequent sedimentation are the most important problems that threaten our soil and water resources. In this research conducted between the year of 2009-2013 in BalıkesirBigadiç-Kocadere Watershed, it is aimed to determined sediment yield based on the rainfall, runoff and suspended sediment measurements in subwatershed. 5 year measurement results covering the years 2009-2013 were evaluated in the research. Sediment rating curve of the watershed has been derived from flow rate and suspended sediment measured with automatic sediment sampler at the subwatershed. With reference to this, annual average sediment yield of subwatershed was 2.11 ton ha-1 $\mathrm{yll}^{-1}$. At the same time, in order to estimate of watershed sediment yield, MUSLE (Modified Universal Soil Loss Equation) equation was used. Sediment yield estimated by MUSLE for the research period was 2.22 ton $\mathrm{ha}^{-1} \mathrm{yll}^{-1}$. The applicability of the MUSLE model under watershed
\end{abstract}


conditions was tested with sediment data measured in the field during 13 individual events and obtained coefficient of determination was 0.92 . MUSLE gave better results in predicting sediment yield for high storms.

Keywords: Balıkesir Bigadiç, watershed, MUSLE, sediment yield, soil erosion

\section{Giriș}

Verimli arazilerde verim kaybına, toprak yapısında bozulmalara, tașkın riski ve zararının artmasına ve su depolama yapılarının hacminin azalmasına sebep olan etkenlerin bașında sedimantasyon gelmektedir. Mülga EiEi Genel Müdürlüğü ile DSi Genel Müdürlüğünün uzun yıllık süspanse sediment miktarı ölçüm sonuçlarına göre, ülkemizin akarsularından ortalama yılda 118.866.090 tonluk süspanse sediment tașınımı olmaktadır. Bu değer ülkemizin 766.878 km²'lik net yağıș alanından tașınan miktardır. Buna \% 25'lik yatak yükü miktarı eklendiğinde tașınan toplam sediment miktarının 148.582.613 tona ulaștığı belirtilmektedir. Diğer yandan Türkiye için hesaplanan alan ağırlıklı ortalama süspanse sediment verimi 155 ton $\mathrm{yll}^{-1} \mathrm{~km}^{-2}$ olarak bulunmuștur. Sediment iletim oranının \% 20 olarak kabul edildiği ülkemizde, erozyonla tașınan toprak miktarı ise $571.471 .585 \mathrm{~m}^{3} \mathrm{yıl}^{-1}$ 'a ulașmaktadır (Anonim, 2015).

Küçük havzalarda $\left(\sim 10 \quad \mathrm{~km}^{2}\right)$ yüzey akıș derinliğinin az ve akımların düzensiz olması nedeniyle sediment verimini saptamada su örnekleme stratejileri önemli rol oynamaktadır. Örneklemenin planlanmasında havza boyutunun ve mevsimin göz önünde bulundurulması gerekmektedir. Akım ölçümleri, örnekleme zamanı, su örnekleme aralıkları ve metotları ile sediment konsantrasyonunu belirleme teknikleri dikkate alınarak, sediment verimi kayıtlarının doğruluğu ile ilgili pek çok araștırma sonuçları yayınlanmıștır. Akım ölçümleri ve sediment örneklemenin doğru zamanlı olarak gerçekleștirilmesi ve doğru șekilde çalıșan aletlerle küçük havzalardan sediment veriminin \%10 dan daha az bir hatayla saptanabileceği belirtilmiștir (Baade ve Liese, 2002).

Akarsu ve nehirlerde sediment hareketinden yola çıkılarak toprak kaybının tahmininde karșılașılan birtakım problemler söz konusudur. Bunlar; örnekleme ya da ölçüm yapmak zaman alıcı ve pahalı olabilmektedir, diğer yandan ölçümlerin doğruluğunun düșük olması olasılığı her zaman vardır, bir akarsuda sediment hareketi ile ilgili iyi veriler olsa bile, toprağın nereden ve ne zaman tașındığı bilinememektedir. Tüm bu problemlere rağmen, farklı akarsularda, yılın farklı zamanlarında ya da farklı arazi kullanımı altında havzalardaki sediment hareketini gözlemlemek ve karșılaștırmak önem tașımaktadır. Sediment iletim ölçümleri birçok basitleștirilmiș kabuller gerektirmektedir. Bunun nedeni sediment tașınımının dinamik bir olay olması ve ölçüm tekniklerinin su kütlesinde, özellikle de akarsu sistemlerindeki sürekli değișen koșulları yeterli doğrulukta tanımlayamamasıdır (Hudson, 1993).

Günümüzde havzalarda sediment araștırmalarına dayalı olarak erozyon süreçlerini daha iyi anlamada, erozyon tahmin teknolojileri yaygın olarak kullanıımaktadır. Zaman içinde yağıș dağılımındaki varyasyonlara bağlı olarak tașınan sediment miktarındaki değișkenliğin yağıș faktörü yerine bir yüzey akıș faktörüyle açıklanabileceğini belirten Williams ve Berndt (1977), havzalarda sediment verimini tahmin etmede, MUSLE modelini önermișlerdir. MUSLE ile sediment veriminin tahmininde doğruluk artmakta ve aynı zamanda sediment iletim oranının belirlenmesine olan intiyaç ortadan kalkmaktadır (Pandey vd., 2009; Banasik ve Walling, 1996; Kinnell ve Risse, 1998; Sadeghi vd., 2004; 2007).

Akarsuda süspanse sediment örneklemesine dayalı olarak havza sediment verimini belirlemek amacıyla, araștırma alanı olan Balıkesir-Bigadiç Kocadere Havzasında alt havza düzeyinde elde edilen ölçüm sonuçları bu çalıșmada değerlendirilmiștir

\section{MATERYAL VE YÖNTEM}

\section{Materyal}

Araștırma alanı olarak belirlenen Kocadere Havzası, Susurluk Büyük Akarsu Havzası içinde Balıkesir Illinin Bigadiç IIlçesinde yer almaktadır. $39^{\circ} 25^{\prime} 12^{\prime \prime} \mathrm{N}$ enlemi, $28^{\circ} 11^{\prime} 52^{\prime \prime} \mathrm{E}$ boylamında yer alan havza $11.366 \mathrm{~km}^{2}$ alana sahip olup, havza maksimum yüksekliği $737.0 \mathrm{~m}$, havza minimum yüksekliği 255.0 m'dir. Havza topoğrafik haritası Șekil 1'de verilmiștir. Havza genel alanının 
\%55. 19 'u çok eğimli ile dik eğime sahip alanlardan olușmaktadır. Arazi yetenek sınıfları bakımından II., VI., VII. ve VIII. sınıf araziler hakimdir. Arazi kullanım türleri ise mera, funda, orman (meșe-çamfıstığı) ve tarım arazisi seklindedir.

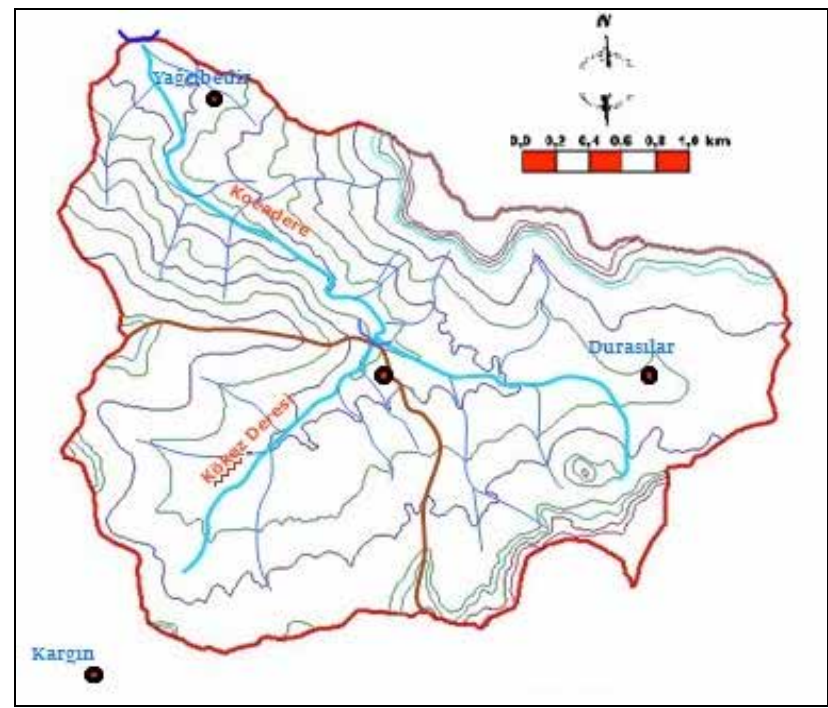

Șekil 1. Kocadere Havzası topoğrafik haritası ve alt havzanın konumu

Figure 1. Topographic map of Kocadere Watershed and location of the sub-watershed

Araștırma kapsamında sediment gözlemleri Kocadere Havzası içerisinde alt havza düzeyinde

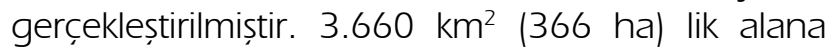
sahip ve 2. dereceden kolu olușturan Kökez Deresi alt havzanın çıkıs kotunda 448 m'de inșa edilmiș olan savak (beșgen yapıda) üzerinde su seviye ölçümleri ve supanse sediment ölçümleri yapılmıștır (Șekil 2). Yağıș verileri ise aynı noktada $450 \mathrm{~m}$ kotunda kurulan yağıș istasyonundan elde edilmiștir. Savak üzerindeki (hız-yükseklik) ölçümlere bağlı olarak,

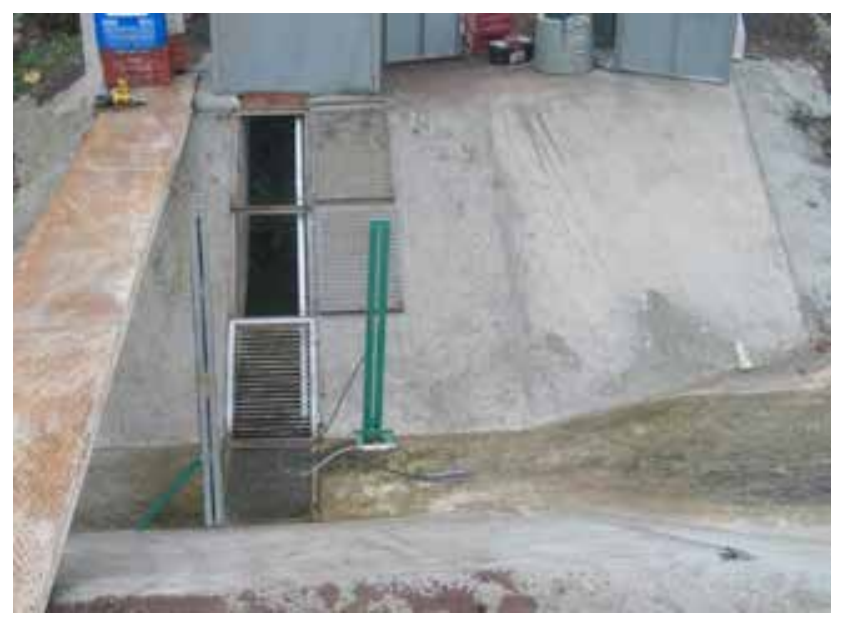

Șekil 2. Akım ve sediment ölçüm noktası

Figure 2. Flow and sediment measuring point su yüksekliği ile debi arasındaki ilișkiyi veren savak anahtar eğrisi denklemiyle $\left(y=1,6615 x^{1,8453}\right)$ süspanse sediment ölçümlerinin gerçekleștirildiği 2009-2013 su yılları için günlük ortalama akım değerleri hesaplanmıștır (Yılmaz vd., 2015).

Sediment örnekleri, programlanabilir özelliğe sahip örnekleyici (Teledyne ISCO 6712) ile bireysel olay bazında alınmıștır. Örnekleyicinin çalıșma prensibi, örnekleyiciye bağlı akım ölçerden su seviye bilgisi iletimine bağlı olarak istenilen aralıkta otomatik bir șekilde su örneğini almaya dayanmaktadır. Bu șekilde bireysel olay bazında 24 adet örnek alma imkanı olmuștur.

\section{Yöntem}

Havzada akarsu ile tașınan toplam sediment (süspanse +yatak yükü) veriminin saptanması için süspanse sedimentin \%'si olarak yatak yükü ilave edilmiștir. Bu oranı belirlemede Maddock (1975) sınıflandırmasından yararlanılmıștır.

Sediment veriminin tahmin edilmesinde uygun tekniği belirlemede havzada etkili erozyon tipine, sediment kaynağına ve uygun verinin olup olmadığına bakmak gerekiyor. Toprak kayıplarının hesaplanması için Wischmeier ve Smith (1978)'in geliștirdiği USLE (Universal Soil Loss Equation) eșitliğinde yer alan yağıș erozivite faktörü yerine yüzey akıș enerji faktörünün esas alındığı Modifiye Edilmiș Üniversal Toprak Kayıpları eșitliği (MUSLE) sediment veriminin tahmininde kullanılmaktadır. Araștırma kapsamında alt havzada sediment veriminin tahmini için MUSLE modeli kullanılmıștır. Modelin gerektirdiği akım verileri, alt havzada savak üzerinde su seviye - debi ölçümlerinden sağlanmıștır.

MUSLE ile sediment verimi așağıdaki ilișkiyle "Eșitlik 1." ifade edilmektedir (Williams, 1975);

$\mathrm{Y}=11.8\left(O q_{\mathrm{p}}\right)^{0.56} \mathrm{~K} L S C P$

Denklemde;

$\mathrm{Y}=$ sediment verimi (metrik-ton)

$\mathrm{Q}=$ yüzey akıs hacmi $\left(\mathrm{m}^{3}\right)$

$\mathrm{q}_{\mathrm{p}}=$ pik debi $\left(\mathrm{m}^{3} \mathrm{sn}^{-1}\right)$

K=Toprak erozyon duyarlılık faktörü (ton ha saat $\mathrm{ha}^{-1} \mathrm{Mj}^{-1} \mathrm{~mm}^{-1}$ )

$C=$ Bitki örtüsü ve ürün yönetimi faktörü

$\mathrm{P}=$ Toprak koruma faktörü

LS=Eğim uzunluğu ve eğim derecesi faktörü 
Eșitlikte yer alan yüzey akıș enerji faktörünün

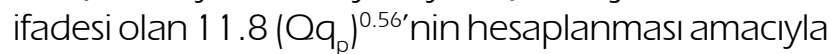
alt havzada ölçülen akımlar Barns metoduna (Barnes, 1940) göre bileșenlerine ayrılmıștır. Böylece her bir bireysel akıma ait yüzey akıș hacmi (O) ve pik debi $\left(q_{p}\right)$ değerleri belirlenmiștir.

Denklemin diğer kısmı için RUSLE (Revised Universal Soil Loss Equation) eșitliğinde yer alan K, LS, C, P faktör değerleri kullanılmıștır. Havza geneline yayılan, GSP ile koordinatları belirlenen 65 noktadan alınan toprak örnekleri $\mathrm{K}$ faktör değerinin belirlenmesinde kullanılmıștır. K faktörü, toprak erozyon duyarlılık eșitliği "Eșitlik 2." (Wischmeier ve Smith, 1978) kullanılarak "t ha saat ha-1 $\mathrm{Mj}^{-1}$ $\mathrm{mm}^{-1}$ " biriminde hesaplanmıștır. Bu eșitliğin metrik sistemdeki karșılığı așağıda verilmiștir.

$K=\left(2.1 \times 10^{-4}\right)\left(12-O M M^{1.14}+3.25(s-2)+2.5(\rho-3) / 7.59 \times 100\right.$

Bu eșitlikte $M$, Eșitlik 3 ile ifade edilmektedir.

$M=(\%$ mil + çok ince kum $)(100-\%$ kin

Burada; K: Toprak erozyon duyarlılık faktörü, OM: \% organik madde, $\mathrm{M}$ : \% birincil tane boyu fraksiyonu, s: toprak stürüktür sınıfı, p: su geçirgenlik sınıfıdır.

Toprak erozyon duyarlıık eșitliği ile elde edilen K faktör değerleri bașlangıç değer olarak alınmıș, mevsimsel etkinin hesaplanmasında USDA 703 numaralı el kitabı esas alınmıștır (Renard vd., 1997). Böylece mevsimsel K faktörünün hesaplanmasıyla her bir toprak örneği için düzeltilmiș K değerleri elde edilmiștir. Düzeltilmiș K değerleri, K faktör haritasının olușturulmasında kullanılmıștır. Kocadere Havzası için $\mathrm{K}$ faktörünün hesaplanan dağılım aralığı 0.0033 ile 0.0266 ton ha saat ha-1 $\mathrm{Mj}^{-1} \mathrm{~mm}^{-1}$ arasında olmuștur. Alt havzada MUSLE ile sediment veriminin tahmini için kullanılan ağırlıklı ortalama K değeri 0.022 ton ha saat ha- $\mathrm{Mj}^{-1} \mathrm{~mm}^{-1}$ olmuștur. Araștırma havzasını kapsayan 1/25000 ölçekli sayısal topoğrafik eș yükselti haritasından olușturulan sayısal yükselti modelinden, Moore ve Burch (1986a; 1986b)'a göre LS faktör katmanı elde edilmiștir. Havzada LS değer aralığının 0-16 olduğu alanlar, genel alanın \% 90'lık bölümünü olușturmuștur. Alt havza için hesaplanan ağırlıklı ortalama LS değeri 5.04 olarak belirlenmiștir. Kocadere Havzasında ekimi yapılan kültür bitkileri (buğday, tütün, mısır) ile mera, fundalık ve orman alanları için ortalama C faktör değerleri, havzada yürütülen arazi ölçüm ve gözlemleri ile RUSLE toprak muhafaza planlama rehberine (Renard vd.,
1997) dayalı olarak belirlenmiștir. Buna göre kültür bitkileri için rotasyon olmadan elde edilen ortalama C değeri 0.23, mera, funda ve ormanlık alanlar için ortalama C değerleri sırasıyla; 0.09, 0.012, 0.003 alınmıștır. Alt havzada MUSLE ile sediment veriminin tahmininde kullanılan ağırlıklı ortalama C değeri 0.13 olarak alınmıștır. Havzada ortalama eğimin yaklașık \%16 olduğu 60.2 ha'lık bir alanda teraslama ve fıstık çamı dikimi yapıldığından, $P$ faktör değeri AH No: 537 (Wischmeier ve Smith, 1978)'e göre 0.14 olarak alınmıștır. Havzanın geri kalan \% 83.55'lik kısmında toprak korumaya yönelik herhangi bir uygulama olmadığından, P değeri 1.0 olarak alınmıștır (Yılmaz vd., 2015).

\section{BULGULAR VE TARTISTMA}

\section{Havza yağıș ve akımları}

Çalıșmada süspanse sediment ölçümlerinin gerçekleștirildiği 2009-2013 periyodunda alt havzada ölçülmüș olan yağıș ve akım verileri bu bölümde değerlendirilmiștir. Alt havzada 2009 su yılından 2013 su yllına kadarki 5 yıllık periyot için elde edilen yıllık toplam yağıș ve akım değerleri Çizelge 1 'de verilmiștir. Bu değerlere göre, 2009 su yılında yıllık toplam yağıș miktarı 937.7 mm olurken, toplam akım değeri 271.5 mm olmuștur. 2010 su yllında kaydedilen yıllık toplam yağıș miktarı $922.8 \mathrm{~mm}$ olurken, toplam akım değeri 194.0 mm olmuștur. 2011 su yılında 796.0 mm toplam yağıșa karșılık, toplam akım 188.6 mm olmuștur. 2012 su yılında toplam yağıș miktarı 768.8 mm, akım miktarı 175.7 mm, 2013 su yılında ise yıllık toplam yağıs $685.6 \mathrm{~mm}$, yıllık toplam akım ise $129.2 \mathrm{~mm}$ olarak kaydedilmiștir. Buna göre araștırma periyodu için ortalama $822.18 \mathrm{~mm}$ yağıșa karșlık, gözlenen akım 191.8 mm olmuștur.

\section{Ölçülen ve tahmin edilen sediment veriminin karșılaștırılması}

Alt havzada süspanse sediment ölçümlerine dayalı elde edilen sonuçlar ile MUSLE eșitliği ile tahmin edilen sonuçlar bu bölümde verilmiștir.

\section{Ölçülen sediment verimleri}

Süspanse sediment örneklemelerinin yapılabildiği bireysel akım olayı sayısı araștırmanın yürütüldüğü yıllar için (2009-2013) sırasıyla; 14, 21 , 9, 3, 16 adet olmuștur. Toplamda 63 adet akıma ait gözlem yapılabilmiștir. Bu gözlemler bireysel akım olayı süresince yada akımın bir kesiti boyunca gerçekleștirilmiștir. Tüm bu akımlar süresince anlık olarak 138 adet sediment örneği alınabilmiștir. 
Değerlendirmede 5 yıllık gözlem periyodu boyunca alınan tüm anlık örnekler biraraya getirilip grafiksel ilișki aranmıștır. Örneklerin alındığı andaki debi değerlerine karșilık tașınan süspanse sediment miktarları arasındaki ilișkiyi veren "sediment anahtar eğrisi"nin grafik ve denklemi Șekil 3'de verilmiștir. Benzer șekilde süspanse sediment miktarı / debi arasındaki ilișkiyi belirlemede Jahani (1992), farklı kategorilere göre sınıflandırma yaparak yürüttüğü bir çalıșmada, en güvenilir sonucun tüm kullanılabilir gözlemlerin birarada analiz edilmesiyle elde edildiğini belirtmiștir.

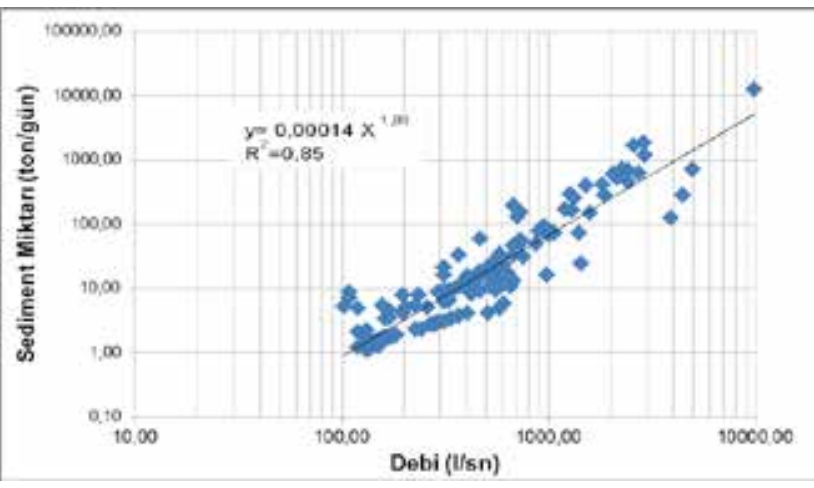

Șekil 3. Havza sediment anahtar eğrisi

Figure 3. Watershed sediments rating curve
Alt havza için elde edilmiș olan sediment anahtar eğrisi denklemi kullanılarak her bir su yılı için hesaplanan günlük süspanse sediment miktarlarının toplamından elde edilen yıllık toplam süspanse sediment miktarları Çizelge 1 'de verilmiștir. Buna göre 2009, 2010, 2011, 2012 ve 2013 su yılları için hesaplanan süspanse sediment miktarları sırasıyla; 884.88; 168.00; 1634.30;

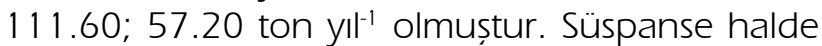
tașınan materyalin \% 69.84 kum, diğer yandan yatak yükü materyalinin ise \% 90'dan fazla kum içerdiği belirlenmiștir. Süspanse ve yatak materyalinin her ikisinin bünyesine ve süspanse sediment konsantrasyonuna dayalı olarak Maddock (1975) sınıflamasına göre süspanse sedimentin \% 35'i yatak yükü olarak alınmıștır. Buna göre 20092013 su yılları için hesaplanan yatak yükü miktarları sırasılyla; 309.71; 58.80; 572.01; 39.06; 20.02 ton $\mathrm{yll}^{-1}$ olmuștur. Elde edilen toplam sediment miktarları ise sırasıyla; $1194.59 ; 226.80 ; 2206.31$;

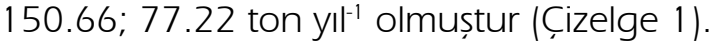

Bu çalıșmada diğer yandan yüksek sediment tașınımına yol açan 3 adet bireysel akım olayı (89-10.2.2009; 17-18-19.12.2011; 13-14.6.2011) için tașınan sediment miktarlarında düzeltmeye gidilmiștir. Bunun için doğrudan süspanse sediment

Çizelge 1. Kökez Deresi alt havzası yağıș, akım değerleri ile akarsu sediment verimi

Table 1. Rainfall, flow values and river sediment yield of the Kökez Creek sub-watershed

\begin{tabular}{ccccccc}
\hline Yıllar & $\begin{array}{c}\text { Yağıș } \\
(\mathrm{mm})\end{array}$ & $\begin{array}{c}\text { Akım } \\
(\mathrm{mm})\end{array}$ & $\begin{array}{c}\text { Süspanse Sediment } \\
\left(\text { ton } \mathrm{yl}^{-1}\right)\end{array}$ & $\begin{array}{c}\text { Yatak Yükü } \\
\left(\text { ton } \mathrm{yll}^{-1}\right)\end{array}$ & $\begin{array}{c}\text { Toplam Sediment } \\
\left(\text { ton } \mathrm{yll}^{-1}\right)\end{array}$ & $\begin{array}{c}\text { Yıllık Sediment } \\
\text { Verimi } \\
\left(\text { ton ha }^{-1} \mathrm{yll}^{-1}\right)\end{array}$ \\
\hline 2009 & 937.7 & 271.5 & 884.88 & 309.71 & 1194.59 & 3.26 \\
2010 & 922.8 & 194.0 & 168.00 & 58.80 & 226.80 & 0.62 \\
2011 & 796.0 & 188.6 & 1634.30 & 572.01 & 2206.31 & 6.03 \\
2012 & 768.8 & 175.7 & 111.60 & 39.06 & 150.66 & 0.41 \\
2013 & 685.6 & 129.2 & 57.20 & 20.02 & 77.22 & 0.21 \\
& & & Ortalama & 771.11 & 2.11 \\
\hline
\end{tabular}

Çizelge 2. Yüksek sediment tașınımına yol açan bireysel olaylar ve sediment miktarları

Table 2. Individual events leading to high sediment transport and sediment amounts

\begin{tabular}{|c|c|c|c|c|c|}
\hline Bireysel akım & $\begin{array}{l}\text { Akım } \\
\text { No }\end{array}$ & $\begin{array}{l}\text { Yüzey Akıș Hacmi } \\
\qquad\left(\mathrm{m}^{3}\right)\end{array}$ & $\begin{array}{c}\text { Ölçülen } \\
\text { Sediment (ton)* }\end{array}$ & $\begin{array}{l}\text { Ölçülemeyen akımın YA hacmi } \\
\text { / Ölçülen akımın YA hacmi }\end{array}$ & $\begin{array}{l}\text { Hesaplanan } \\
\text { Sediment (ton) }\end{array}$ \\
\hline $8-9-10 / 2 / 2009$ & 1 & 172953 & & $\begin{array}{c}1 \text { no'lu akım / } 3 \text { no'lu akım = } \\
0.48\end{array}$ & 675,14 \\
\hline $17-19 / 12 / 2011$ & 2 & 41256 & & $\begin{array}{c}2 \text { no'lu akım / } 3 \text { no'lu akım = } \\
0.12\end{array}$ & 168,79 \\
\hline $13-14 / 6 / 2011$ & 3 & 356760 & 1406,55 & & 1406.55 \\
\hline
\end{tabular}

\footnotetext{
*: doğrudan örneklemeye dayalı hesaplanan sediment
} 
örneklemesi yapılabilen 13-14 Haziran 2011 tarihli feyezan ve bu olaya ait karakteristik özelliklerden olan yüzey akıș hacminden faydalanılımıștır. Yüksek sediment tașınımına yol açan her üç olay için hesaplanan sediment miktarları Çizelge Z'de verilmiștir. Yıllık toplam süspanse sediment miktarları hesaplanırken, her üç bireysel olay için elde edilen sediment miktarları dikkate alınmıștır.

\section{Tahmin edilen sediment verimleri}

MUSLE modeli ile alt havzada sediment veriminin tahmini için, erozif özellik gösteren 80 adet akım incelenmiștir. MUSLE eșitliğinde "Eșitlik 1." yer alan yüzey akıș enerji faktörünün bileșenleri olan yüzey akıș hacmi ve pik debi oranları her bir seçilmiș bireysel akım olayı için hesaplanmıștır. Eșitliğin diğer bileșenleri olan K, LS, C ve P faktör değerlerini RUSLE katmanları olușturmuștur. K, LS, C ve P faktör katmanlarının alt havza için hesaplanan ağırlıklı ortalama değerleri sırasıyla; 0.022; 5.04; 0.13; 0.97 olmuștur. Buna göre araștırma periyodu için eșitlikle tahmin edilen sediment verimleri Çizelge 3'te verilmiștir. Aynı zamanda ölçülen ve tahmin edilen toplam sediment miktarlarının, karșılaștırmalı olarak verildiği Çizelge 3 incelendiğinde, araștırma periyodu için ölçülen ve eșitlikle tahmin edilen

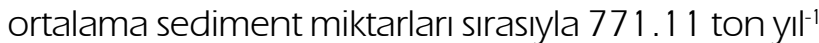

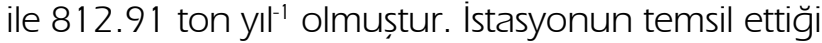
havzanın (366.0 ha) birim alanından gelen ortalama yıllık sediment verimi ise yine sırasıyla; $2.11 ; 2.22$ ton ha' ${ }^{-1} \mathrm{yll}^{-1}$ olmuștur. Diğer yandan ylllar itibariyle sediment verimleri incelendiğinde, yüksek sediment tașınımına yol açan feyezanların kaydedildiği yillar olan 2009 ve 2011 'de, hesaplanan tahmin hatasının (\%18, \%-44) ve aynı zamanda tahmin edilen/ölçülen sediment oranının (1.2; 0.6), diğer yıllara göre daha düșük olduğu görülmektedir.

Çizelge 3. Ölçülen ve MUSLE ile tahmin edilen yıllık toplam sediment veriminin karșılaștııılması

Table 3. Comparison of measured and estimated total annual sediment yields

\begin{tabular}{|c|c|c|c|c|}
\hline Yillar & $\begin{array}{l}\text { Toplam ölçülen } \\
\text { sediment (ton) }\end{array}$ & $\begin{array}{l}\text { Tahmin edilen } \\
\text { sediment (ton) }\end{array}$ & Tahmin hatası (\%) & $\begin{array}{c}\text { Tahmin edilen / } \\
\text { Ölçülen oranı }\end{array}$ \\
\hline 2009 & 1194.59 & 1414.37 & 18 & 1.2 \\
\hline 2010 & 226.80 & 516.97 & 128 & 2.3 \\
\hline 2011 & 2206.31 & 1234.59 & -44 & 0.6 \\
\hline 2012 & 150.66 & 467.85 & 211 & 3.1 \\
\hline 2013 & 77.22 & 430.76 & 458 & 5.6 \\
\hline Ortalama & 771.11 & 812.91 & & \\
\hline Toplam & 3855.57 & 4064.53 & & \\
\hline Yıllık Sed. Verimi (ton ha ${ }^{-1} \mathrm{yll}^{-1}$ ) & 2.11 & 2.22 & & \\
\hline
\end{tabular}

Cizelge 4. MUSLE'nin test edilmesinde kullanılan akımların karakteristik özellikleri

Table 4. Characteristics of flows used in testing of MUSLE

\begin{tabular}{cccccc}
\hline No. & Akım tarihi & Süre (saat) & Yüzey akıș hacmi $\left(\mathrm{m}^{3}\right)$ & Derinlik $(\mathrm{mm})$ & Pik debi $\left(\mathrm{m}^{3} \mathrm{~s}^{-1}\right)$ \\
\hline 1 & $5-6 / 1 / 2009$ & 15 & 37695.21 & 10.065 & 2.18 \\
2 & $26-27 / 3 / 2009$ & 33 & 21880.8 & 5.843 & 0.98 \\
3 & $3-4-5 / 1 / 2010$ & 55 & 20194.2 & 5.392 & 0.50 \\
4 & 14.2 .2010 & 12 & 36054 & 9.627 & 2.85 \\
5 & 6.3 .2010 & 8 & 5004 & 1.336 & 0.84 \\
6 & 7.3 .2010 & 14.5 & 8272.8 & 2.209 & 0.54 \\
7 & $13-14 / 6 / 2011$ & 39 & 356760.0 & 95.263 & 13.38 \\
8 & 15.4 .2012 & 20 & 34167.14 & 9.123 & 2.00 \\
9 & 20.1 .2013 & 14 & 3607.2 & 0.963 & 0.37 \\
10 & $22-23 / 1 / 2013$ & 10 & 4989.6 & 1.332 & 0.75 \\
11 & 25.1 .2013 & 8 & 7171.2 & 1.915 & 1.02 \\
12 & 23.3 .2013 & 6 & 1692 & 0.452 & 0.33 \\
13 & 5.4 .2013 & 8 & 2653.2 & 0.708 & 0.26 \\
\hline
\end{tabular}


Çizelge 5. Alt havzada MUSLE'nin uygulanmasının sonuçları

Table 5. Consequences of the application of MUSLE in the subwatershed

\begin{tabular}{cccccc}
\hline Sıra No. & Akım tarihi & $\begin{array}{c}\text { Toplam ölçülen } \\
\text { sediment kütlesi } \\
\text { (ton) }\end{array}$ & $\begin{array}{c}\text { Tahmin edilen } \\
\text { sediment kütlesi } \\
\text { (ton) }\end{array}$ & $\begin{array}{c}\text { Toplam ölçülen } \\
\text { sediment verimi } \\
\text { (ton ha } \text { (1) }^{-1}\end{array}$ & $\begin{array}{c}\text { Tahmin edilen } \\
\text { sediment verimi } \\
\text { (ton ha } \text { h }^{-1}\end{array}$ \\
\hline 1 & 23.3 .2013 & 2.65 & 5.70 & 0.01 & 0.02 \\
2 & 20.1 .2013 & 3.77 & 9.28 & 0.01 & 0.03 \\
3 & 7.3 .2010 & 4.06 & 18.26 & 0.01 & 0.05 \\
4 & 5.4 .2013 & 4.13 & 6.34 & 0.01 & 0.02 \\
5 & $22-23 / 1 / 2013$ & 9.26 & 16.53 & 0.03 & 0.05 \\
6 & 6.3 .2010 & 11.27 & 17.65 & 0.03 & 0.05 \\
7 & $26-27 / 3 / 2009$ & 11.61 & 43.83 & 0.03 & 0.12 \\
8 & 25.1 .2013 & 17.09 & 24.07 & 0.05 & 0.07 \\
9 & $3-4-5 / 1 / 2010$ & 21.74 & 28.70 & 0.06 & 0.08 \\
10 & 15.4 .2012 & 131.67 & 84.21 & 0.36 & 0.23 \\
11 & $5-6 / 1 / 2009$ & 213.05 & 93.26 & 0.58 & 0.25 \\
12 & 14.2 .2010 & 259.92 & 105.70 & 0.71 & 0.29 \\
13 & $13-14 / 6 / 2011$ & 1898.84 & 906.98 & 5.19 & 2.48 \\
\hline
\end{tabular}

MUSLE modelinin havza koșullarında uygulanabilirliği, arazi çalıșması sırasında süspanse sediment örneklemelerinin yapılabildiği 13 adet bireysel akım olayı için elde edilen sediment verisi ile test edilmiștir. Söz konusu akımların karakteristik özellikleri Çizelge 4'te özetlenmiștir. 13 akım olayı için ölçülen ve MUSLE ile tahmin edilen sediment verimleri Çizelge 5'te verilmiștir. Çizelgede de görüldüğü gibi, bu çalıșmayla MUSLE'nin küçük akımlar söz konusu olduğunda, ölçülen değerlere kıyasla yüksek değerler verdiği belirlenmiștir. Benzer șekilde Williams ve Berndt (1977) küçük akımlar için sediment verimini tahmin etmede MUSLE'nin tatmin edici sonuç vermediğini belirtmișlerdir. Aynı zamanda Johnson vd., (1985); Sadeghi (2004); Sadeghi ve Mizuyama (2007) bu sonucu doğrulamıșlardır. Diğer yandan bu çalıșmada, yüksek sediment tașınımına yol açan bir akım söz konusu olduğunda tahmin edilen ve ölçülen değerlerin birbirine yaklașmakta olduğu görülmüș (Șekil 4), ancak MUSLE yüksek akımlarda gözlenen değerlere göre daha düșük sediment tahmini yapmıștır. Benzer șekilde Pandey vd., (2009), MUSLE modelinin büyük akımlar için nispeten daha düșük sediment verimi tahmininde bulunduğunu belirtmișlerdir.

Seçilmiș olan her bir bireysel akım olayı için tahmin edilen sediment verimleri ölçülen sediment verimleriyle karșılaștırıldığında, her iki veri seti arasındaki ilișkiyi gösteren belirtme katsayısı $\left(R^{2}\right) 0.92$

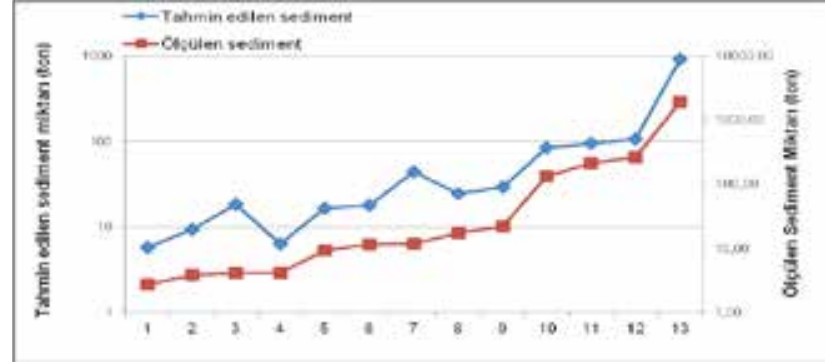

Șekil 4. Ölçülen ve tahmin edilen sediment grafiği

Figure 4. Measured and estimated sediment graph

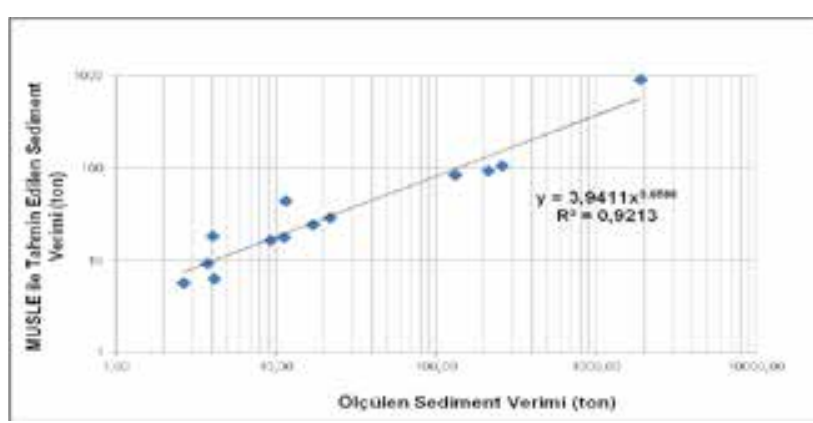

Șekil 5. Ölçülen ve tahmin edilen sediment veriminin karșillaștırıması

Figure 5. Comparison of measured and estimated sediment yield

olmuștur (Șekil 5). Yapılan bir çalıșmada MUSLE ile sediment verimi tahmininde 6 adet akım olayı için modelin geçerliliği test edilmiș ve benzer șekilde yüksek belirtme katsayısı (0.99) elde edilmiștir (Arckhi vd., 2011). Bir diğer araștırmada Pandey vd. (2009), MUSLE ile tahmin edilen sediment 
verimlerini gözlemlenen değerlerle karșılaștırmıșlar ve elde ettikleri yüksek belirtme katsayısının (0.83) modelin, sediment verimi tahmininde bașarıı olduğunu gösterdiğini belirtmișlerdir.

\section{SONUCLAR}

Sediment verimi tahmininde kullanılan MUSLE modelinin, küçük akımlar söz konusu olduğunda arazi ölçümlerine dayalı elde edilen sediment verimi değerlerine kıyasla daha yüksek tahminde bulunduğu belirlenmiștir. Ancak yüksek sediment tașınımına yol açan bir akım söz konusu olduğunda ise MUSLE tahminlerinin gözlenen değerlere göre göreceli olarak daha düșük olduğu, özellikle feyezan akımlar için sediment verimi tahminininde modelin daha iyi sonuçlar verdiği belirlenmiștir.

MUSLE modelinin havza koșullarında uygulanabilirliği, arazide ölçülen sediment verisiyle test edilmiș ve elde edilen belirtme katsayısı değeri (0.92) yüksek bulunmuștur. Bu da uygun kalibrasyonun yapılması halinde modelin benzer koșullarda daha iyi sonuçlar verebileceğini göstermektedir. Bir sonraki çalıșmamı bu kapsamda olacaktır. Bu çalıșma ile, havzalarımız için yüksek doğrulukta sediment grafiklerinin olușturulmasında çok sayıda bireysel olayın izlenmesine yönelik örnek çalıșmalara gereksinim olduğu bir kez daha anlașılmıștır.

\section{KAYNAKLAR}

Anonim (2015). http://www.eie.gov.tr/eie-web / kurumsal_istatistikler / çevre_ist / hidroloji / sediment.html (Erișim Tarihi: 03.07.2015).

Arckhi S, Shabani A, Rostamizad G (2011). Application of the modified universal soil loss equation (MUSLE) in prediction of sediment yield (Case study: Kengir Watershed, Iran). Arab J. Geosci DOI 10.1007/s12517-010-0271-6.

Baade J, Liese C (2002). Accuracy of sediment yield measurements in small catchments. Erosion and Sediment Transport Measurements: Technological and Methodological Advances. Workshop in Oslo 19-21 June 2002.

Banasik K, Walling DE (1996). Predicting sediment graphs for a small agricultural catchment. Nordic Hyrdol. 27(4), 275294.

Barnes BS (1940). Discussion of analysis of runoff characteristics. Trans ASCE 105:106.

Hudson NW (1993). Field measurement of soil erosion and runoff. Food and Agriculture Organization of the United Nations.

Jahani I (1992). Calculating the suspenden sediment load of the Dez River. Erosion and Sediment transport Monitoring Programmes in River Basins (Proceedings of the Oslo Symposium, IAHSPubl. no.210.
Johnson CW, Gordon ND, Hanson CL (1 985). Northwest Rangeland sediment yield analysis by the MUSLE. Transactions of the American Society of Agricultural Engineers, 28:18891895.

Kinnell PIA, Risse LM (1998). USLE-Mempirical modeling rainfall erosion through runoff sediment concentration. Soil Sci.Soc. Am.J. 62, 1662-1672.

Maddock T (1975). Table 3.2 in Sediment Engineering, V.A. Vanoni(ed.) ASCE, New York.

Moore I, Burch G (1986a). Physical basis of the lengthslope factor in the universal soil loss equation. Soil Science Society of America Journal 50: 1294-1298.

Moore I, Burch G (1986b). Modeling erosion and deposition: topographic effects. Trans of Asae 29(6): 16241630, 1640.

Pandey A, Chowdary VM, Mal BC (2009). Sediment yield modelling of an agricultural watershed using MUSLE, romote sensing and GIS. Paddy Water Environ (2009), 7: 105-113. DOI 10.1007/s10333-009-0149-y.

Renard KG, Foster GR, Weesies GA, Mccool DK, Yoder DC (1997). Predicting soil erosion by water: a guide to conservation planning with the Revised Universal Soil Loss Equation (RUSLE). Handbook No. 703. US Department of Agriculture, $404 \mathrm{pp}$.

Sadeghi SH (2004). application of MUSLE in prediction of sediment yield in İranian conditions. ISCO2004-13th International soil conservation organization conferenceBrisbane, July 2004

Sadeghi SHR, Singh JK, Das G (2004). Efficacy of annual soil erosion models for storm-wise sediment prediction: a case study. Int. Agric.Engng. J.13 (1/2), 1-14.

Sadeghi SHR, Mizuyama T (2007). Applicability of the Modified Universal Soil Loss Equation for prediction of sediment yield in Khanmirza watershed, Iran. Hydrological Sciences-Journal-des Sci. Hydrologiques, 52(5).

Sadeghi SHR, Mizuyama T, Ghaderi VB (2007). Comformity of MUSLE estimates and erosion plot data for storm-wise sediment yield estimation. J. Terrest. Atmos. Oceanic Sci. 18(1), 117-128

Williams JR (1975). Sediment-yield prediction with Universal Soil Loss Equation using runoff energy factor.p.244-252. In: Present and Prospective Technology for Predicting Sediment Yield and Sources. U.S. Dep. Agr. ARS-S 40

Williams JR, Berndt HD (1977). Sediment yield prediction based on watershed hydrology. Trans. Am. Soc. Agric. Engrs 20(6), $1100-1104$.

Wischmeier WH, Smith DD (1978). Predicting Rainfall erosion Losses - A Guide for Conservatin Planning (Agricultural Handbook 537). Washington, DC: USDA.

Yılmaz G, Șahin Taysun K, Acar CO, Özden N, Aruğaslan L, Bilir L, Taysun A, Uysal H (2015). Kocadere Havzasinda RUSLE ile Potansiyel Toprak Erozyonunun Belirlenmesi ve Toprak Korunumunun Planlanmasi. Tarımsal Araștırmalar ve Politikalar Genel Müdürlüğü yayını (UTAEM 2015-02), (Proje Sonuç Raporu), İzmir. 